\title{
Introducing Values of Local Cultural Through Batik Motifs as The Identity of Surabaya City
}

\author{
Tirta Dimas Wahyu Negara \\ Universitas Negeri Surabaya \\ Surabaya, Indonesia \\ negaratirta20@yahoo.co.id
}

\begin{abstract}
The recognition of UNESCO towards batik as Indonesia's cultural heritage makes batik industries grow rapidly. Batik is currently used by the local government as a political media in introducing excellence and as an image of the region through the visual display of a particular icon that it symbolized. This research took place in Surabaya city as the location of observation. This study uses the approach of cultural studies and theories of semiotics as the main theory. The research results are expected to be used as educational media to introduce to the next generation to know the local values and the identity of the city of Surabaya. This is because the icon made on batik motif is a form of depiction of local art, historic buildings, special foods, until the flora and fauna typical Surabaya city. The results showed that the creation of batik motifs cannot be separated from the role of local government that seeks to create batik motifs according to regional identity. Batik characteristic of Surabaya has represented regional identity based on the concept of creation and meaning of batik itself, viewed based on motif, technique, color and composition.
\end{abstract}

\section{Keywords - local cultural values, batik motifs}

\section{INTRODUCTION}

Surabaya is the largest city in East Java Province with a population of 3,035,363 people in the metropolis (data from the Occupation and Record Service). It is no doubt if the city of Surabaya is often a reference in the field of trade, industry, education and culture. But in the world of art (batik) in particular, Surabaya seems still not dominate, especially in East Java Province. Many opinions assume that batik development in this metropolitan city is still far below other cities in East Java.

In fact, batik industries in Surabaya are still productive. Attention given by Surabaya city government can make batik craftsman able to survive in modern era like today. This is proven by the motif of ayam bekisar (ayam sawnggaling), motif daun semanggi, suro and boyo motif as a typical motif representing the identity of Surabaya.

United Nations Educational, Scientific, and Cultural Organization is a United Nations specialized agency (UN) established in 1945. The purpose of this organization is to support peace and security by promoting cooperation between countries through education, science and culture. Since UNESCO established batik as world cultural heritage on October 2, 2009, almost all regions develop batik.
This also happens to batik craftsmen in Surabaya City, supported by the local government to align the production of craftsmen in Surabaya with batik of other areas, especially in East Java Province. This is evidenced by the frequent exhibition of batik theme lifted Surabaya. Batik was deliberately created to describe the characteristics of the city of Surabaya.

Characteristic is an identical characteristic of a person or an object and a distinction between one thing and another. The characteristics of an object can be seen from the display, the way of making and the constituent components. The concept of creation of art is a belief or idea that emerges in one's mind based on logical thinking (make sense) then make the idea as a guide in life according to the purpose of the thinking.

While culture according to [1] culture is not stand alone, but related to various aspects of life. Indonesia is an archipelago, multisite and multicultural country. Each tribe has a culture with all its local wisdom. The researcher of cultural interpretation is a thing that is passed down from generation to generation to create a custom called culture. This opinion is in line with the phrase that culture is an experience in everyday life: sharing the texts, practices and meanings of everyone in their lives $[2,3]$.

Identity basically refers to the reflection of a thing or individual who has differences from the like. Cultural identity is a characteristic or characteristic of a culture owned by people we know its limits when compared with the characteristics or characteristics of other people's culture [4, 5]. Thus, cultural identity can be interpreted as a depiction of a certain activity that is done down and down between one generation and the next generation in an effort to preserve the form of a culture.

[6] explained that there are 3 ways of identity formation. The first is primordial, that is the formation of identity that emphasizes the naturally acquired identity or the cultured identity. The second is constructivism, an identity formation that emphasizes the identity gained by the process of interaction. Third, instrumentalism, the formation of identity that occurs due to the construction of the ruler, the existence of the interests that make up this identity. 
Based on these reviews researchers try to discuss more related to batik Surabaya. The focus of the discussion includes characteristics of batik motifs, concept of creation, meaning of batik motifs and role of Surabaya government.

\section{METHOD}

This research is descriptive qualitative research with cultural studies approach, this approach sees the establishment of a critical perspective, in which the concept of culture can be seen as a product and response to social conditions from a certain period of time. According to [7] the object of cultural studies is not a culture defined in a narrow sense, as an object of aesthetic but a culture understood as text and everyday practice.

The main theory this research use is semiotics, according to $[8,9]$ the term semiotics was used in the 18 th century by the German philosopher Lambert, as the equivalent of Logic. If interpreted then semiotics is the study of the mindset of the form of a person's work through symbols or icons that appear. In contrast to writing, each of the image markings is representative of the relative and total of a certain maxim [10].

Research steps to be undertaken: (1) searching for information related to batik Surabaya, by visiting several craftsmen who have been determined before; (2) conducting interviews with informants to know the relationship between concept of creation of batik motif and culture of Surabaya; (3) recording all forms of observation activities conducted, including the process of question and answer during the interview; (4) copying the results of the interview into written data to be submitted back to the resource persons for the validity of the data, accompanied by the signature of the relevant informant; (5) perpetuating all matters relating to resource and re-search object, documentation of manuscripts, photographs, catalogs, magazines, more result and discussion.

\section{RESULT AND DISCUSSION}

\section{A. Characteristics of Batik as a Cultural Identity}

Characteristics of a batik can be seen from various aspects of the background. Among them are aspects of color, aspects of motifs, aspects of manufacturing techniques and motif composition.

\section{1) Characteristics of Color Batik Surabaya}

If viewed from the classification of batik type based on place of production, batik Surabaya is included in the category of coastal batik. The main characteristic of coastal batik is seen from the selection of strong and striking colors. Besides, coastal batik does not have a special grip in terms of coloring. If we group them in the coloring category, then the batik in the city of Surabaya is identical with the colors firmly with strong characters such as purple, blue, red, green, black and white. $[11,12]$ batik costoal also developed in Madura, Aceh, Jambi, Palembang, Bengkulu, Borneo, Toraja and Bali.

\section{2) Characteristics of Surabaya batik motif}

Batik motifs in Surabaya can be regarded as a batik motif that is not bound by rules. Viewed in terms of shape, color, and meaning, each motif has a different historical background.
They are such as the historic buildings, typical art, typical food and also daily life of the community. Surely this does not depend on two main factors that can be concluded by the researcher.

First is the factor of the absence of mutual agreement between batik craftsmen with other craftsmen, batik craftsmen with local government, batik craftsmen with cultural and local historians to be able to equate opinions about batik of Surabaya. The second factor is the dynamic and varied mindset and life of Surabaya City, which is one of the strongest factors to influence the acculturation of culture from various ethnic, racial, and ethnic groups in Surabaya.

Both opinions can be seen in the example of some cases of Surabaya batik motifs that describe the acculturation of the culture of the community, the batik motifs of Cheng Hoo Mosque and Dragon Statue in Kenjeran District.

3) Characteristics of technique of making batik Surabaya

During the process of data collection, the researchers tried to see and find the location of the difference from the stage of the creation of batik Surabaya. The focus of the researcher is on the use of tools dominated by electronic canting. The number of complaints will be the use of more complicated manual canting, then the batik craftsmen in Surabaya began to switch to electronic media canting. The reason is for the efficient and time-efficient way to control the degree of scratching the main factor. Surely not all batik craftsmen in Surabaya use these tools.

4) Characteristics of Composition of Surabaya batik motif

In the opinion of [13] the main motif ornament is a decoration that has meaning, so that the composition of the main motif will affect the soul or spirit of the motif itself. While the additional motif or called isen-isen is complementary motif serves as a filler field. Isen-isen batik motif of dots, lines, combined point and line.

Referring to the above discussion, we can distinguish batik motifs into 2 categories namely geometric motifs and non geometric motifs. Geometric motif is a description of the main motif neatly arranged and has a "raport" or certain parts that become geometric patterns, while non-geometric motif is an arrangement of ornaments whose arrangement does not have a certain grip.

\section{B. Concept of creation and meaning of batik motif}

Herry, the head of art and cultural section of Culture and Tourism Office of Surabaya City on May 29, 2017, explained that most of batik business in the city of Surabaya create batik motifs with typical iconic city of Surabaya. Consisting of suro and boyo motifs that implies the values of struggle and character of Surabaya people who are hard, firm and not easily give up according to the story of fish (suro) and crocodile (boyo) legend. Ayam bekisar motif contains the meaning of luxury, then semanggi motif gives a high spirit meaning in living life and jarak arum motif means the process of life change. The concept of creation of each craftsman is based on a variety of reasons. But the outline of each craftsmen create batik motifs is with the aim to respond to the local government 
that gives the demand to batik craftsmen to be able to create batik with motifs representing identity of origin.

\section{The role of government in batik preservation and development}

Referring to the opinion of [14] who explains that the role is a set of behavior that is expected by others to someone according to his position in a system. In general, the government of Surabaya City plays a role in the procurement of places for gathering craftsmen, facilities for craftsmen to sale batik products and batik training places for all batik craftsmen in the city of Surabaya. Here is a detailed division of government roles for individual and group of batik craftsmen:

1) Ownership of trade business license granted by the Department of Industry and Trade of Surabaya City;

2) Training batik periodically by the Department of Industry and Trade Surabaya (the selection);

3) Provision of facilities in the form of tools and materials of batik, by the Department of Industry and Trade of Surabaya (temporary);

4) Provision of exhibition booth for batik festival in Surabaya City, Surabaya Industry and Trade Office (selection);

5) Grant funding through BKR program and CSR Program, by State-Owned Enterprises in the form of Limited Liability Company namely PT. Telkom Indonesia, PT. Semen Gresik and Family Planning Youth program by Family Planning;

6) Provision of opportunities to follow the demo batik abroad, by the Government of East Java Province;

7) Provision of quotas for IKM products that will be placed in the batik house as a souvenir for the guests of the Mayor of Surabaya either from within or outside the country.

\section{CONCLUSION}

Batik's characteristic as a cultural identity representing the portrayal of Surabaya City is being encouraged by the local government. The goal is a means of education to the public to love batik culture. In addition, the presence of batik motifs are specifically created to represent the characteristic depiction of Surabaya that can be used as a tool to introduce characteristic of the city of Surabaya through batik motifs. Many of the batik motifs depict the historic buildings, typical art, typical food and the folklore that has been legendary. If viewed in terms of place of manufacture, batik Surabaya included in the category of coastal batik. Characterized by a color that is very diverse and striking.

Most of Surabaya batik has motifs based on the idea of creating nuanced animals and plants, such as ayam bekisar motif, suro and boyo motif, naga motif, teripang motif, arum jarak motif, semanggi motif. Nevertheless the batik craftsmen in Surabaya still bring the character of objects with strong historical values, for example the character of Bambu Runcing monuments, Cheng Hoo Mosque, Suramadu Bridge and Tugu Pahlawan. When viewed from the structure of the shape, batik Surabaya is a blend of geometric and non-geometric motifs. What has been done by each batik craftsmen in Surabaya city according to ethnography perspective is an effort to pour ideas into one's thinking, obtained by seeing, hearing and feeling various types of certain activities in their daily life.

The concept and meaning contained from every batik motif in Surabaya City is very diverse. Some are based on the love of cultural heritage, some are based on the destruction of the natural environment and some are based on the desire to clean up by removing the negative image that exists. Broadly speaking, the meaning of batik motif in Surabaya City seeks to introduce the potential of nature, culinary potential, and artistic potential contained in the city of Surabaya. When viewed from the perspective of cultural theory, the formation of Surabaya batik motifs created by the demands of the elite (local government) to become a souvenir of the city of Surabaya. Although not all batik motifs created because of these demands, but it can be labeled most of the batik motif of IKM batik production in Surabaya is created by instrumentalist. So the identity of the characters that appear have a specific purpose.

Furthermore, the researcher suggests Surabaya government to be able to create a special forum to bring together batik craftsmen, cultural, historians and related institutions to determine what characters can represent the depiction of the city of Surabaya. The results of this study can also be used as a reference to protect Surabaya batik motifs with the copyright (IPR) Intellectual Property Rights.

\section{REFERENCES}

S. Y. Sudikan, "Kearifan Budaya Lokal," Ssidoarjo-JawaTimur: Damar Ilmu, 2013.

C. Barker, Cultural studies: Theory and practice: Sage, 2003.

S. Hall, "Cultural studies and its theoretical legacies," Stuart Hall: Critical dialogues in cultural studies, pp. 262-275, 1996.

A. Liliweri, Dasar-dasar komunikasi antarbudaya: Pustaka Pelajar, 2003.

M. J. Collier and M. Thomas, "Cultural identity: An interpretive perspective," Theories in intercultural communication, vol. 99, p. $122,1988$.

J. Suryo, "Pembentukan Identitas Nasional," in Makalah Seminar Terbatas Pengembangan Wawasan tentang Civic Education, LP3 UMY, Yogyakarta, 2002.

J. Storey and L. Rahmawati, Cultural studies dan kajian budaya pop: pengantar komprehensif teori dan metode: Jalasutra, 2008.

P. Cobley, Semiotics: Wiley Online Library, 1999.

A. Sachari, Metodologi penelitian budaya rupa (desain, arsitektur, seni rupa dan kriya): Erlangga, 2005.

N. Syam, Antropologi: PT LKiS Pelangi Aksara, 2007.

A. Wulandari, "Batik nusantara: makna filosofis, cara pembuatan dan industri batik," Yogyakarta: Penerbit Andi, 2011.

C. L. Lee, Batik: creating an identity: National Museum Singapore, 1991.

R. Yulianto, M. Hariadi, and M. H. Purnomo, "Fractal Based on Noise for Batik Coloring using Normal Gaussian Method," IPTEK, vol. 23, p. 34, 2012.

D. Katz and R. L. Kahn, The social psychology of organizations vol. 2: Wiley New York, 1978. 